\title{
Commentary
}

\section{Fake News and Non-Corporate Players during a Mining Boom - Justice Denied?}

\author{
Margaret O'Callaghan \\ Independent Researcher \\ Canberra \\ margaret@ocallaghan.id.au
}

\begin{abstract}
A review of reports about the impact of a recent mining boom in Zambia reveals a surprising number to be inaccurate and misleading, some even defamatory. The authors were mainly non-government organisations (NGOs) but academics, consultants and journalists were also guilty of misreporting. A single inaccuracy may not be significant, but added up they constitute a widespread practice that amounts to 'fake news'. This must be challenged, not least because it diverts attention from the real nature of mining related problems. This paper describes the issues, analyses possible reasons for them and suggests some solutions. It challenges all investigators to lift their game. Some of the methodological issues raised are complex and present quandaries that need to be addressed by the various players. The paper recognises that serious problems have been caused by some mining companies and accurately reported, and that some NGOs have done good work with communities. This story refers to the opposite side of that coin, a subject that may not have been comprehensively reported before. Though Zambia is the focus below, many of the matters raised are likely to be relevant in other countries in the southern African region.
\end{abstract}

\section{Introduction}

This paper arose from the author's research on the impact of the first decade of the North Western Province Zambia mining boom, c. 2002-2015 (O'Callaghan 2018a, 2018b, 2019). The prevalence of 'fake news' was unexpected but it became apparent that the practice constituted a form of injustice that should be challenged.

Non-corporate players, and especially non-government organisations (NGOs), have become very active during this century's mining boom in 
southern Africa, largely in response to the many serious problems being reported by mining communities. They have stepped in to fill the void left by governments that failed to vigorously assess licence applications, to monitor mining developments closely and to ensure maintenance of standards. The Zimbabwean mining minister stated frankly to a regional ministers' conference in 2014 that "most of the mining activities on the continent have been opaque and detrimental to Africans" (African Union Commission 2014). In many countries NGOs have empowered mining communities by educating them about their rights and how to advocate for them, and by documenting and publicising the issues affecting them.

However, not all investigations and reporting in recent years have been rigorous and accurate. These weaknesses resulted in the publishing of what could be called 'fake news'. Such reporting, when recognised for what it is, undermines the credibility of NGOs and other authors in the eyes of the public, donors and mining companies.

\section{The Appearance of Fake News}

The mining boom in North West Zambia commenced about 2002, and from 2007 NGOs increasingly provided a much-needed source of education about land and community rights to both large and small-scale mine communities in urban and rural areas. By 2010 others were starting to arrive to investigate mining impact, including academics and consultants working for international organisations. Many reports and commentaries appeared. It was a remarkable 'boom' in what had previously been a relatively quiet, largely rural area; it had never before been so heavily studied in such a short period.

A review of the various publications showed that the NGOs in particular were well intentioned in their efforts to promote the welfare of local communities and that they provided some useful and appreciated inputs. They were playing an active watchdog role. However, the quality of their reporting was quite variable and it became apparent to this author, who had spent eight years studying the mining situation in the North West, that some authors were providing 'fake news'. Some information was factually inaccurate, some situations were seriously misinterpreted or exaggerated and some of the reporting was even defamatory to mining companies. Issues were not restricted to NGOs but also, at times, included academics, consultants and the media. 


\section{Weak or Flawed Methodology}

Problems with research methodologies appeared to be the underlying cause of most of the subsequent reporting problems. Evident were weak terms of reference, often too ambitious; inadequate resources to carry out a study effectively, including funds and time for adequate preparation and analysis and sharing of drafts; lack of appropriate expertise including both appropriate qualifications and experience; lack of benchmarks and use of both quantitative and qualitative data without triangulation and adequate sampling; over-reliance on anecdotes; and being superficial in approach. Almost all writers mentioned shortage of time under the 'Limitations' section of their reports and so it was not surprising that their results were weak. One university consultant, for example, had plans to visit six mines and three Chambers of Commerce in one week, involving traveling hundreds of kilometres, making for a hectic schedule and rushed interviews (company communication, 2015). Another consultant was allocated only thirty days for visiting eleven locations across two provinces hundreds of kilometres apart, viewing dozens of community development programs and writing up (Abner Bright 2015).

Some NGO staff, while often having language and culturally appropriate and community-friendly knowledge and skills, demonstrated a lack of technical and analytical capacity. Such problems were not confined to NGOs. The Zambian Environmental Management Agency (2017) reported similar problems with the consultants involved in nation-wide environmental assessment reporting and advertised for help to improve their capacity. But while weak writing skills can be partly excused, poor analysis and factual inaccuracies cannot. The latter undermine the value of reports and the credibility of NGO arguments, however real some of the underlying community issues might be. Consequently, NGOs do a dis-service to the very people they are aiming to serve.

Many reports indicate that the authors were unaware of what earlier work had been done or some basic sources of information. They could be accused of being lazy in not having done their home-work but it is common knowledge that it is often difficult to find relevant information. It is not always on-line and sources lie in a wide range of organisations, including companies, NGOs, academia, the media and various government departments. The last is especially challenging. Annual reports may not be published for some years and officials may be reluctant to provide information, perhaps because the data are weak or they are afraid of revealing problems that might embarrass a government. While company annual reports are publicly available, information on community aspects tend 
to be 'glossy' and provide only superficial information. Such reports can be open to question about their accuracy and balance.

\section{Negativity and Bias}

The extent of negativity and bias identified in many reports was surprising and disturbing, as was the exaggeration of issues and the adversarial tone often used. The relationship between mining companies and NGOs (and often the media) has historically not been a positive one. There are good reasons for this, especially in areas where there are long-standing, poorly run mines with serious legacy issues, as on the Zambian Copperbelt and in South Africa. The industry now publicly admits that mining has big issues when it comes to dealing with the environment and local communities. The executive director of AngloAmerican South Africa, for example, conceded that the industry had often "... over-promised and under-delivered, [and ] that it needed to redress legacy issues and ... [win] credibility and ... trust, especially with local communities" (Environmental Resource Management 2014).

However, NGO antagonism was not confined to mining matters, for there was already a history of negative attitudes in the broader NGO world, at least in Zambia. In 2004 former President Mwanawasa criticised NGOs "for acting as opposition parties rather than being partners in development" (Geloo 2004). Six years later, the Diocesan Caritas Coordinator Frederick Nabanda said, rather nicely, that "civil society was not against investors and the government but were actually looking for the best way for a common approach to solving people's problems and improving their standard of living" (Mwakikagile 2010, p. 122). Charles Kasonde, the Bishop of Solwezi, spoke out on the subject in 2014, pointedly reminding NGOs that the government "was not on a different side from civil society, [and] that they were working for the same cause", to alleviate poverty (Kasonde 2014). Graça Machel noted weaknesses in NGO performance at the 2015 Alternative Mining Indaba in Cape Town and challenged delegates to ensure that their advocacy efforts were smarter, more strategic, factual and measurable. Later that year at the African Natural Resources Centre meeting in Johannesburg she reiterated that NGOs "were the voice of the people and the protectors of their national interests", but she also emphasised that they must stop talking in generalities (Solomons 2015).

A clear bias and adversarial tone was shown in the Southern Africa Resource Watch report (SARW 2018) sub-titled 'First Quantum Mine versus Communities in Zambia (emphasis added). Negativity is expressed through the use of emotive, inflammatory language and over-dramatising issues, 
perhaps done as a means of attracting attention. The practice can at times be understood, and sometimes justified, because NGOs and the communities they represent are often been frustrated by the lack of response to issues they have raised. Such emotive calls are a cry of agony and frustration from the heart, as it were. However, their use does not justify the exaggeration of issues to the extent that reports constitute a falsification of situations. It has even been suggested that NGOs may be trying to earn 'extra mileage' from their donors for being able to raise such dramatic 'noise' because they need to justify their cost. This may be true of some but cannot be an excuse for inaccurate reporting.

Particularly exaggerated examples were the reports entitled 'Land Grabs by Extractive Industries in Zambia' (Caritas et al. 2015) and 'Kalumbila Land Grab, The Unfolding Drama of Greed, Economic Sabotage, Cultural Aggression and Injustice' (Secretariat, Musele Nkisu Taskforce 2014). A social media article dramatically proclaimed that Kalumbila mine "forced people into concentration camps" (Solwezi West Constituency Watch 2015), while the 2018 SARW report section heading read 'Chasing communities from their land'. An ActionAid presenter inaccurately reported at the Zambian Alternative Mining Indaba (ZAMI) in 2019 that women were forced to give up bags of maize (Author's notes on presentation, ZAMI, 2019). NGOs also put out two unnecessarily alarmist and un-evidenced reports on Uranium (Civil Society for Poverty Reduction 2007/Caritas Solwezi 2011 and Council of Churches in Zambia 2010). Lumwana reported that some of these NGOs told local people that they "would soon be extinct" because of the mine (correspondence 2019). In another example, an academic blog posting exaggerated the extent of community resentment about outsiders obtaining jobs, saying that the company was 'predisposing the area to heightened ethnic conflict'. Such a term is heavily loaded and implies mass violence and worse, which was an exaggerated version of what was happening (Kapesa et al. 2015).

These were all classic, misleading stories, amounting to the spreading of 'fake news'. While there have been serious problems in some places, it doesn't help an argument to describe a situation in such inflammatory language. It is an antagonistic approach that puts both the companies and government off-side and risks making them less willing to take up and address the genuine issues being raised. While the sense of frustration over the lack of action on some matters is understandable, the use of emotive language is a cheap way of attracting attention. It is hard to take such a report seriously and makes it easy to dismiss as 'just another NGO rag'. Having 
strong factual information to back a case would have much greater impact and earn more respect.

But what should NGOs do when there are genuine problems and they aren't being responded to by government and companies and communities continue to suffer? Sometimes they do have to beat a very loud 'drum' to attract attention to their cause - and often that attention is through the media. Sometimes reports of 'fake news' are challenged in the public arena. The SARW report (above) was reported again in the Daily Maverick by one of its authors, reiterating the dramatic and negative information previously published (Lange 2019). Mills, a Brenthurst Foundation commentator, responded scathingly. He not only (rightly) asked why it had published such an inaccurate and antagonistic report but noted that it seemed to be a biased and purposeful ploy to tarnish the reputation of the company. It was the authors, he said, "who are living in a parallel universe in presenting such a shoddy piece of work ... Perhaps that should be expected of a simple hatchet job riddled with factual inaccuracies and bogus assumptions" (Mills 2019).

Another example came from an academic who interpreted the upgrading of the Kansanshi Smelter road as a negative activity (Kesselring 2018). In fact, the upgrading had been approved by the Council as a sensible, relatively simple and minimally disturbing way of greatly reducing the number of mine trucks going through the centre of town

Where such negativity exists it inevitably breeds bad feelings and especially distrust between companies and NGOs, sometimes for quite different reasons. In one case around 2012 a staff member of a mining company social team declined a request for a particular NGO to be represented on a committee to help support the community's interests. This was at a time when many community problems were occurring and unfortunately the company was defensive and unable to respect NGO advocacy efforts, because, as he said, "they were always complaining". But it happened to be a period when the community complaints were welljustified and the company was not as experienced in dealing with community issues as it might have been.

On another occasion an NGO representative was shocked when another company staff member refused a request to undertake an investigation in their area. In this case there were good reasons, the company having been inundated with such requests (as discussed below). The NGO concerned seemed unable to accept that there was a legitimate reason, failing to understand the bigger picture and jumping to a negative conclusion about the company not being open to investigation at that time. 
Companies have also tended to be very negative about NGOs because they have, on numerous occasions, published reports which contain many factual errors and misinterpretations - as this current research discovered. Company distrust of NGOs is well justified in such cases, particularly as such accusations risk their reputation and share price. The spreading of such 'fake news' is not conducive to a positive, respectful and cooperative relationship, but instead fans deep distrust.

Some NGOs have run an almost entirely antagonistic campaign against mining companies, with a singular lack of public appreciation of what the companies have contributed. For example, there are various groups of local people in Solwezi who have benefited economically in various ways from the mining boom - but their successes are rarely reported by NGOs. Why not?

It is a similar situation with communities themselves. A consultant for a Lumwana study observed that local community members seemed to be loathe to recognise the mine's contributions because it might mean that there would be no more benefits, "that accepting that their livelihoods had somewhat improved [as a result of the mine] would jeopardise their quest for supplementary compensation" (Imakando 2013, p. 7). At Kansanshi it took over a decade for local communities to come to understand that many of the problems which had occurred were actually due to a negligent government (community report to author 2014).

There have been few positive public reactions from Chiefs. One exception appeared in a United Nations Development Program supported video (2015), 'Mining in Zambia, opportunities and challenges', in which Chief Mumena and Senior Chief Mukumbi gave public recognition to the contributions made to their communities in terms of construction of schools, teachers' houses and health centres. Chief Mumena also made the insightful comment that they had finally 'developed mutual trust' - which hadn't been the case in earlier years - again an indication of how relationships can mature as time goes by. This point is elaborated below.

\section{Failing to Contextualise}

NGOs could have recognised that the problems in the North West were less severe than on the Copperbelt or in South Africa. The situation in the mining sector is changing for there have been improvements globally over the past decade in environmental and social-related policies and approaches, as Franks (2015) describes. There are stronger checks in place and the cost of not doing the right thing is now very high for the reputations of companies and consequently their share prices. 
While the improvements may be occurring far too slowly in some places, those reviewing a situation need to come to an area with an open mind, and not just jump to foregone conclusions. It is hardly justice to pre-judge what is going on, even when some problems are obvious. The roles played by other actors also need to be considered before the finger is pointed, especially taking into account the roles of national and local government, traditional authorities, local businesses and even the communities themselves. These targets are less easy to attack than are the major mines.

It is also important to be aware that smaller mines are run by 'junior' companies which are far less in the public eye than the 'majors' like First Quantum and Barrick Gold. They are likely to be far less well-resourced and to lack social expertise. Consequently, they are more likely to be associated with community related and other problems, but with far less publicity than that given to the 'majors'. This issue was discussed at the Environmental Resource Management Special Session (2014), where it was also pointed out that the industry tended to be "judged by the poorest performer."

\section{Misdirecting Blame}

Accusations have commonly been directed at companies as easy targets, but the 'enemy may be within', as Tanzanian Regional activist priest Father Jude pointed out at the 2013 ZAMI (author's notes 2013). That is, problems may well be due to national, provincial or local governments. It is easier for NGOs to blame a mining company than a government, a step which would risk an NGO getting into government's 'bad books' and possibly being deregistered. It is equally politically sensitive to accuse a local elite (including sometimes a traditional leader) of misdemeanours. An accused company is placed in an uncomfortable position for it is unlikely to feel free to correct the situation by criticising its host government. Nor is it easy for a company to defend itself against an NGO without looking defensive, and no company has yet taken the major step of suing an NGO for defamation.

Another misdirected charge is of companies 'land grabbing, and again the responsibility rests with the government that approved a licence to an investor in order to encourage economic development. It is also a step to which the local Chief must have already agreed. In fact, many community members would be angry if a Chief turned down a mining opportunity, as one Chief told this author in 2014.

There are many reasons as to why governments may be at fault but suffice to say, that as Bishop Kasonde did in an understated way at the 2014 ZAMI , that "government was taking a low profile"- that is, about matters it should have been actively supervising or monitoring. It is very clear that government 
(at all levels) had often been missing from the equation when it came to protecting community rights. At times this omission has been due to lack of capacity, but at other times political will has been clearly lacking. Some NGOs mis-directed their arguments by blaming local government when the issues were national.

\section{Reporting Issues}

Many issues arose in the subsequent write-ups of the various investigations. A key omission which weakened many report findings was the failure to contextualize what was being observed, to understand the bigger picture in which issues or events were occurring. In particular, investigators often failed to appreciate the stage at which a mining related community was at when they interviewed people, especially those who had been relocated. In any such situation there is an inevitable period of often uncomfortable adjustment: firstly the excitement and high hopes, followed by the anxiety about what is happening; then shock when things don't turn out as expected; disappointment when riches don't immediately accrue to individuals; then anger and blame. Finally, there is gradual adjustment and perhaps resignation to the new situation when things are more settled. As an NGO leader said, "the relationships are dynamic and keep changing" (communication to author 2015). Progressing through such stages can take a number of years.

Another contextual factor is the stage of development of the mine. Fewer unskilled jobs are needed once a mine moves into production and modern mines use fewer human resources than did the older mines, points often not appreciated by those who criticise companies for not employing more staff or laying some off when phases change.

\section{Recognising and Understanding Complexity}

It is also important to recognise the complexity of the changes that have been occurring. It is easy for a visitor to judge simplistically and to focus on the 'noise', the dramatic, and to fail to spend time finding out about what a company, government or communities had or had not done. Lusaka journalist Jack Zimba became aware of this issue when he reported on some dramatic incidences in 2014. He wisely concluded by saying that it was "hard to know the truth when all the parties involved point accusing fingers at each other ... I leave Solwezi with a dreadful sinking feeling that maybe I, too, may have missed the real story" (Zimba 2014).

A postgraduate student also admitted that even after "all these interviews I still don't know what is going on ... there are a lot of contradictions... I 
have become more confused than before." (communication with author 2014). A company social scientist reiterated the same point, writing that social and economic conditions "are complex, snapshot visits/interviews don't even scrape the surface" (correspondence with author 2015).

It is important to review the broader context and ask questions: for example, who these people are, whether they are local or part of the influx who have not obtained work, or families deserted by miners, or people who have been displaced and used up their compensation in non-sustainable ways, or if they lack strong guidance from their traditional leaders. Is it government, the company or Chiefs being remiss in not attending to their needs or instead their own fault that they are experiencing difficulties? The answer is not necessarily a simple one and likely to be due to a combination of factors.

\section{Generalising, Misinterpretation and Misrepresentation}

There was much generalising in reports. A good example was the use of the term 'community' as if the people in a particular area were homogenous - when in fact major mining areas are far from being so. This is not just because of the influx of outsiders (who themselves are of mixed backgrounds, although with a predominance from the Copperbelt). But the locals are never entirely Kaonde or Lunda or Luvale, as can be seen from the environmental impact assessment reports and other surveys, and most include other North Westerners. Also, communities are not static.

Many were guilty of generalisations. Statements like the "local community did not feel that the Lumwana Mining Company is employing local candidates" (Abner Bright 2015) and villagers being quoted as saying that "we suspect pollution" and "polluted water could be the source of diarrhoea" (SARW 2018) are all vague generalisations and insinuations, not strong evidence.

Also common was a failure to understand or interpret the views and motivation of affected communities which had already been discussed in an earlier publication (O'Callaghan 2018a). Those investigators, most being short-term visitors to a mine area, are unlikely to appreciate local politics and the subtle forms of control that are sometimes exerted by leaders, including sanctions, threats of witchcraft and physical force. Misleading responses are not very surprising in a desperately cash-poor environment where there is always hope that more cash will be forthcoming if one can plead appropriately.

A good example of this was reported by the Institute for Poverty, Land and Agrarian Studies (IPLAAS 2016). Reporting on the new resettlement housing, an informant (who was on the negotiating team disputing 
government-set compensation rates) noted that the people had 'good' houses before, with three to four bedrooms, but that they have been given twobedroom houses. As with most such complaints there was an element of truth in this story and some issues with the new homes. But an interviewer who did some probing would soon realise that the informant was biased and that their previous houses were typically formed with small, hand-made, baked brick walls, earth floors and thatched roofs, with no windows or proper doors - hardly comparable to what was provided by the company.

Some reports misrepresented the nature of their investigations, claiming for example to have 'extensively consulted' mining companies when it was known that they were only in the area very briefly and didn't meet officers as described (company communication, 2014). One reporter 'parroted' information without acknowledging that the information was from a company presentation they had attended, not from an interview. Another falsely claimed he knew the community well (correspondence with author 2014). Some also reported that a company would not see them when in fact time was made available but it did not suit the interviewer, or else the company staff were simply busy at the time they called (company information 2018).

\section{Factual Errors}

A surprising number of writers had a few, or in some cases many, basic facts incorrect. One academic even had twelve factual errors in a published paper (Correspondence 2017). A Columbia University group (2012) also made many errors, including saying caterpillars were a major source of protein and that Barrick Gold was a South African company and had discovered uranium while mining. They even failed to mention that Kaonde was the local language. But the previously mentioned 2018 SARW report was the most heavily marred report seen - with many basic factual errors and some interpretations being extraordinary and unjustified. Another researcher reported that there had been a "lack of consultation with and participation by mine affected communities" when in fact there was much well documented evidence of dozens of meetings having taken place with participants' names and comments documented (Coastal \& Environmental Services, 2012). IPLAAS also inaccurately reported in 2014 about Kalumbila that the Chief had not been consulted, that there were no proper agreements and nothing was being done about livelihoods.

Another mistake repeated on more than one occasion by different authors was about how much the mines procure from within Solwezi or Zambia when common sense would indicate that the figures cited were quite unrealistic 
when most items were technical/industrial and Zambia does not produce them. Even when procured from Solwezi, registered items such as stationery and uniforms will have been produced elsewhere, usually in South Africa (Chilufya 2015).

A commonly aired complaint has been that the Corporate Social Responsibility (CSR) has been minimal and inadequate over the years. Such a view can be easily dispelled if investigators take the time to review the very expansive CSR programs being implemented and other local support provided, in addition to other contributions being paid in taxes at the local and national levels. It might not be enough to solve all of the North West issues but it is undeniably substantial assistance - which should be recognised.

Not only are such errors concerning but they risk being repeated by others who rely uncritically on an author, contributing to setting such false information in stone. This includes what is communicated through the media, unless like Zimba, they suspect they might have been misinformed, and admit it.

\section{Role and Use of the Media}

NGOs using the media have a powerful role to play as a conduit and amplifier through which community issues can be publicised and authorities, if communities are unable to do so effectively themselves because of their lack of knowledge and experience. The media can be a powerful tool in advocacy. As Franks (2015) reported about an unresolved Chilean mining community problem, the conflict and the media attention it attracted "translated the community's whispers into a strong voice that could be heard." Such amplification can be powerful when issues are genuine and a company has been seriously remiss in certain areas. But untrue accusations constitute a misuse of power and can antagonise a company and rightly cause it to deeply distrust the instigator. Any resulting publicity is likely to bring a company's reputation into disrepute, thereby creating a serious business risk. The relationship between the two parties would undoubtedly deteriorate and the perpetrator would risk being sued.

The media can also be a dangerous weapon in other ways as it thrives on the dramatic and emotive and has a tendency to 'shoot from the hip', leaving hard facts behind. It is also much easier and faster for journalists (as with NGOs) to describe a situation in black and white and to ignore the underlying complexities which invariably exist in any mining community. An article by the Sisters of Notre Dame (2015), for example, picked up globally by Thomson Reuters, was full of inaccuracies. It was later withdrawn after the 
company provided corrections to the publisher, but by that time the damage was done to its reputation (in fact it is still available on the web). Daily Maverick also picked up Lange's 2019 article about the SARW report, not realising that the source was heavily flawed.

Companies, it is true, have a tendency to create false impressions in their public relations. Articles and photos are almost guaranteed to be positive renditions of how helpful the company has been to local communities, as in First Quantum's glossy annual reports of 2013 and 2016, and their press releases. The superb photography, with happy smiling faces and encouraging economic achievements of some, belied the reality of many affected people's lives. The magazine Solwezi Today (which is funded by various companies) provides many such examples about company CSR activities. Only one article in the two years reviewed described the downside of a mining boom, providing an overview of the difficulties prevailing at Manyama. Notably, that story was by a journalist rather than a company media staff member (Solwezi Today 2012). Barrick Gold, however, published a realistic report on the issues caused by the in-migration to the same area (Barrick Gold 2012). But if no one else writes positive news about company CSR activities it is not surprising that they wish to fill the void.

The use of mobile phones and social media channels has made it much easier than in the past for information to be shared publicly and very quickly. However, the downside of this development is that superficial, knee-jerk reactions can be spread dangerously quickly, as they did during the difficulties being experienced at Kalumbila around 2012-14. Such publicity can only too easily stir up emotions and seriously mislead as to the real nature of the issues. A Change.org petition raised by a South African activist about Kalumbila (van Wyk 2013) added fuel to the media coverage at the time by failing to get its facts correct. This exercise constituted an example of inappropriate use of the petition mechanism and created another example of 'fake news'.

\section{Understanding Company Context and Investigation Overloads}

Awareness of some facts about mining companies would assist researchers. The three major mines in the North West have been inundated with researchers of various types over the past decade, making for a heavy workload for their staff. Some investigators have submitted lengthy questionnaires to companies, including many that could be answered by consulting company websites. For example, in 2015 ILO submitted thirtyfour questions covering seven and a quarter pages, while in 2019 Swedwatch submitted thirty-one questions in three pages (Author has copies). 
Companies complained that they rarely received a copy of the final reports. Also, as much as they can be expected to discuss community related matters with researchers they should not be responsible for doing their basic 'homework'.

In addition to meeting such demands, major mining companies are regularly and irregularly subject to various types of audits, including financial, environmental, management and CSR, including assessing compliance with Equator Principles and International Finance Corporation standards. As well, the Zambian government undertakes assessments and internal auditors makes assessments from a business risk perspective. Much mines are also subject to constant ad hoc requests from the media, members of parliament and the like for mine visits. Recognition of these investigation overloads would aid appreciation of why companies may have difficulty with dealing with researchers, especially those who have very narrow windows of availability or have not done their homework. Also, and ideally, draft reports should be submitted for correction of fact and possible questioning of interpretation to companies, although again that would be yet another drain on their time.

\section{The Implications of Spreading Fake News}

One could argue that some of the examples noted by this author were minor in themselves, but others were not. The Caritas Norway study (2013), for example, concluded that the Norwegian Pension Fund should consider investing in other industries rather than mining. This was potentially extremely serious for the company, First Quantum, as the Fund was a large shareholder. The company argued that the findings were not justified by the information presented and noted numerous errors of fact and interpretation. The author refused to adjust her report and agreed only to add an addendum - but by this time it was too late because the report had already been launched in Zambia and Norway.

Such a response was surely unethical behaviour by that consultant, let alone one working for a Church based organisation. She was new to Zambia, on a very short and wide-ranging mission, and, not surprisingly, appears to have been unable to distinguish all the facts and the broader context of the situation. She may have also been biased by having been to the Copperbelt before the North West and therefore primed to find problems because of the obvious and very serious issues there. She certainly didn't understand the broader context. Much time-consuming follow-up had to be undertaken by the company to address this issue, including involving the Norwegian Ambassador to Zambia. 
The 'Parallel Universe' report by SARW (2018) had similarly negative implications for the same company's reputation. Not only was it adversarial in its sub-title, but it also used highly emotive language and made serious unsubstantiated allegations, including a statement that CSR investments "maintain and perpetuate poverty and under-development." This situation was more difficult to address than the Norwegian one partly because SARW was also extraordinarily resistant to correction and refused to withdraw the report. Eventually they agreed to reinvestigate the situation, with a new report about to be made available. Curiously, it was not clear from their website who their funders were after June 2018 and so it was not possible to challenge their supporting organisation. This was a strange omission for an NGO which states in its mission statement (SARW website, accessed September 2019) that it works for "transparent and accountable utilisation ".

Another implication of the spread of 'fake news' is that some doors are closed to researchers. Barrick Gold now has a policy not to 'entertain' researchers at Lumwana mine (staff communication 2019) and has refused to communicate with this author in recent years, despite the courtesy of a draft report having been provided by this author. This is presumably a global policy because of the problems with very negative NGO reports the company experienced in other countries about especially problematic issues, including at Porgera in Papua and New Guinea and North Mara in Tanzania (with Acacia). But closing the door to all communication does nothing to resolve issues, and is in fact, also damaging to a company's reputation. Such a policy is hardly relevant to the situation at Lumwana which was a relatively peaceful environment. In contrast, First Quantum's two mines, Kansanshi and Kalumbila, have in recent years, followed a policy of being open and informative - albeit at a significant cost to their time and patience when misreporting occurs, and when researchers turn up poorly prepared.

\section{Possible Solutions}

Researchers and their sponsors should ideally ensure that:

- Sufficient preparation is undertaken

- The terms of reference are realistic

- Sufficient time, money and appropriate expertise is provided

- Researchers have good analytical and writing skills

- Qualitative and quantitative information is used and facts are checked

- A range of information collection techniques are used and data triangulated 
- Generalisations and emotive/sensational language are avoided

- An understanding of the context is obtained, including the stage of the community developments and the stage of the mine

- All levels of government are consulted

- A draft is submitted to the company for corrections of fact (where possible).

But these requirements present a quandary. Masters and post-graduate students and NGOs are rarely sufficiently well-resourced to fulfil all these requirements. Academics may be in a hurry to 'publish or perish'. The media want a quick snapshot of a situation and prefers the sensational.

NGO funding agencies need to be much more aware of the potential for 'fake news' about the impact of mining and to take responsibility for ensuring quality control. They should not take reports at face value just because they are being reported by NGOs, assuming that their good intentions are enough to guarantee accurate reporting.

This author has proposed that it might help researchers to establish a unit similar to that run by the Rhodes-Livingstone Institute in earlier days (Van Donge 1985). A resource centre could usefully be established to hold relevant documents, to act as an advisory body and share information, including through seminars. It could also play a role in coordinating research, although it is appreciated that this a somewhat controversial proposal. Who would fund it so that it remains neutral and acceptable to the diverse parties is a key question.

\section{Conclusions}

Investigators can provide valuable insights into mining impacts, but some reporters have acted 'as messiahs with instant solutions' (Kupe 2019). The analysis above helps to explain why the situation has been so negative and what is needed to improve the situation. However, many of the lessons learned present NGOs and other investigators with issues that are difficult to resolve given widespread resource and time constraints. There is also the question of attitude, of being sufficiently open minded and aware to undertake research without bias, and to approach the task in a manner that can win the respect of a company (and on occasion, governments and elites) so that findings will be heard and taken on board. In other words, they need to act professionally, but they will need help in doing so. Relevant parties, including donor agencies, need to be recognise the issues and discuss them openly if realistic solutions are to be found so that justice prevails and all parties receive a fair hearing. 


\section{References}

Abner Bright for ILO. (2015). "Job and Wealth Creation Impact of Mining

Community Development Programmes in Zambia". December.

African Union Commission. (2014). Extraordinary Conference of African

Ministers of Mineral Resources, Victoria Falls.

Alternative Mining Indaba. (2015). Cape Town.

Barrick Gold. (2012). Managing In-Migration at Lumwana', Barrick Beyond Border, $11^{\text {th }}$ December.

Caritas Norge. (2013). Who Benefits? Norwegian Investments in the Zambian Mining Industry. November.

Caritas Zambia, Zambia Land Alliance and Ndola Diocese. (2015). Land Grabs by Extractives Industries in Zambia, Impact on land user rights and the livelihoods of the local communities of Solwezi, Ndola, Mana, Mazabuka and Siavonga. (Draft report).

Civil Society for Poverty Reduction. (2007). Pilot Assessment on the Impact of Livelihoods of the Poor in Solwezi and Kasempa District NWP.

Chilufya, C. (2015). For the Jesuit Centre for Theological Reflection. Baseline Study on the Level of Social Service Provision and Community Awareness and Involvements in CST Projects in Solwezi.

Civil Society for Poverty Reduction and Caritas Solwezi. (2011). Discovering Fate: Uranium Mining and the People of Lumwana.

Coastal \& Environmental Services. (2012). Sentinel Deposit, North Western Province Zambia, Environmental Impact Assessment, Addendum. November. Prepared for Kalumbila Minerals Ltd.

Columbia University. (2012). A Report on Challenges in Natural Resource Management in Northwestern Province Zambia. Centre for International Conflict Resolution.

Council of Churches in Zambia (2010). Prospecting Until Death.

Environmental Resource Management. (2014). Highlights of the 2014 Mining Indaba. Saving time and money through pro-active management of health, safety, community and environmental risks mining indaba and a summary of ERM's special topic .workshop http://www.erm.com/globalassets/documents/events/2014/miningindaba-highlights.pdf

Franks, D. (2015). Mountain Movers, mining, sustainability and the agents of change, Earthscan from Routledge, London and NY.

Geloo, Z. (2004). Quoting the President. "NGOs in the Hot Seat", Inter Press Service News Agency. www.ipsnews.net/africa/interna.asp?idnew $\mathrm{s}=22739$ 
Imakando, M. (2013). Report on the Status of Economically Compensated Community Members, for Barrick Gold. (October).

Institute for Poverty, Land and Agrarian Studies. (2016). Changing Agro-

Food Systems. The impact of big agro-investors on food rights Case studies in Mozambique and Zambia.

Kabemba, C. and Lange, E. (2018). 'Living in a Parallel Universe: First Quantum versus the mining communities in Zambia'. Southern Africa Resource Watch.

Kapesa, R., Mitwa, J. and Chikumbi, D. (2015). Social Conflict in the Context of the Development of New mining Concessions in Zambia. Southern African Peace and Security Studies, Vol. 4, No. 2.

Kasonde, C. (2014). Opening remarks, Zambian Alternative Mining Indaba, Ndola. (June 17th). (author's notes).

Kesselring, R. (2018). The local state in a new mining area in Zambia's North Western Province. Chapter 7 in J. Schubert, U. Engel, and E. Macamo (Eds.), Extractive Industries and Changing State Dynamics in Africa : Beyond the Resource Curse. (Routledge Studies in African Development). Routledge.

Kupe, T. (2019). Why science matters so much in the era of fake news and fallacies. The Conversation. (March $18^{\text {th }}$ ).

Lange, E. (2019). 'Poverty, toxic water and disease as Zambian mine offers no hope of social transformation.' Daily Maverick. (February $19^{\text {th }}$ ). https://www.dailymaverick.co.za/article/2019-02-19-poverty-toxicwater-and-disease-as-mine-offers-no-hope-of-social-transformation/

Mills, G. (2019). 'Southern Africa Resource Watch and Zambia: What are they trying to achieve?' Daily Maverick. (February $20^{\text {th }}$ ).

Mwakikagile, G. (2010). Life in an African Country. Dar es Salaam: New African Press.

O'Callaghan, M. (2018a). Research Issues in a recent Zambian mining boom. Some on-site observations. https://crawford.anu.edu.au/ rmap/devnet/devnet/db-79.pdf

O'Callaghan, M. (2018b). "Africa Focussed Mining Conferences: An overview and analysis". http://afsaap.org.au/assets/39 2 151-197.pdf

Secretariat, Musele Nkisu Taskforce. (2014). Kalumbila Land Grab. The Unfolding Drama of Greed, Economic Sabotage, Cultural Aggression and Injustice, 2010-2014.

Sisters of Notre Dame de Namur Justice, Peace and Integrity of Creation. (2015) 'Women pay the price for Zambian mining expansion'. Thomson Reuters, September.http://www.reuters.com/article/uszambia-mining-women-idUSKCN0RF02D20150915 
Solomons, I. (2015). Machel Urges Civil Society organizations to play more active role in natural resources sector. Mining Weekly. (November $\left.27^{\text {th }}\right)$.http://m.miningweekly.com/article/call-for-greater-transparency -in-natural-resources-sector-2015-11-27

Solwezi West Constituency Watch. (2015). 'Kalumbila FQM forcing local people into concentration camps.' Facebook. (October $28^{\text {th }}$ ).

Solwezi Today. (2012). Lacking Amidst Plenty: The Story of Manyayma. Issue 6, Volume 2, Feb., p. 12.

Southern Africa Resource Watch. (2018). 'Living in a Parallel Universe. First Quantum Mine versus Communities in Zambia'. Resource Insight, Issue 17, November.

Southern Africa Resource Watch. (nd). Website, under 'Home'. Accessed at https://www.sarwatch.co.za/

United Nations Development Programme. (2015). 'Mining in Zambia, opportunities and challenges' www.youtube.com/watch?v=JX2RS fB60s\&feature=youtu.be

Van Donge, J. (1985). Understanding rural Zambia today: The relevance of the Rhodes-Livingstone Institute. Africa, 55(1), 60-76. doi: $10.2307 / 1159839$

Van Wyk, 2013. Petition to GRZ to stop FQML from making 'a massive land grab'. Change. Org petition, October.

Zambian Environmental Management Agency. (2017). Press release, $21^{\text {st }}$ February, Call for Submissions.

Zimba, J. (2014). 'The Two Faces of Solwezi', Zambian Post. 25 November. http://jackjzimba.blogspot.com/2014/11/the-2-faces-ofsolwezi.html 